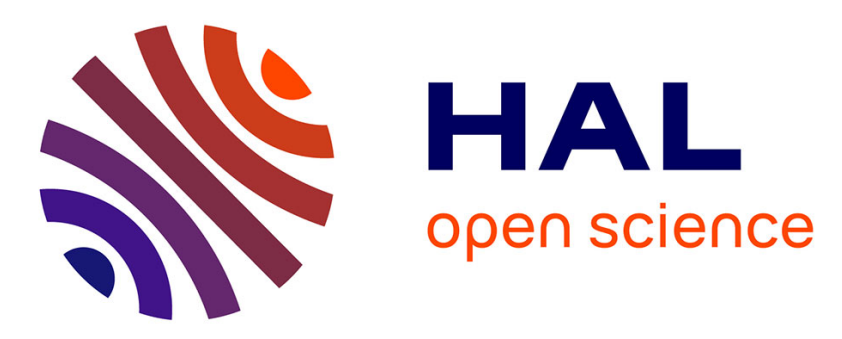

\title{
Palladium-Mediated Phosphine-Dependent Chemoselective Bisallylic Alkylation Leading to Spirocarbocycles
}

\author{
Hervé Clavier, Laurent Giordano, Alphonse Tenaglia
}

\section{To cite this version:}

Hervé Clavier, Laurent Giordano, Alphonse Tenaglia. Palladium-Mediated Phosphine-Dependent Chemoselective Bisallylic Alkylation Leading to Spirocarbocycles. Angewandte Chemie International Edition, 2012, 51 (34), pp.8648-8651. 10.1002/anie.201204629 . hal-01409144

\author{
HAL Id: hal-01409144 \\ https://hal.science/hal-01409144
}

Submitted on 5 Dec 2016

HAL is a multi-disciplinary open access archive for the deposit and dissemination of scientific research documents, whether they are published or not. The documents may come from teaching and research institutions in France or abroad, or from public or private research centers.
L'archive ouverte pluridisciplinaire HAL, est destinée au dépôt et à la diffusion de documents scientifiques de niveau recherche, publiés ou non, émanant des établissements d'enseignement et de recherche français ou étrangers, des laboratoires publics ou privés. 


\title{
Palladium-mediated phosphine-oriented chemoselective bis allylic alkylation leading to spirocarbocycles
}

\author{
Hervé Clavier, * Laurent Giordano, * and Alphonse Tenaglia*
}

As highlighted by numerous works, allylic substitution is a versatile transformation in organic synthesis and one of the most powerful tools for the formation of carbon-carbon and carbon-heteroatom bonds. ${ }^{[1]}$ Transition-metal-promoted allylic substitutions were found particularly useful since they allow for the installation of stereogenic centers in an enantioselective fashion. ${ }^{[2]}$ Among the various metals competent for this reaction, palladium-catalyzed allylation of soft nucleophiles, so called Tsuji-Trost reaction, has been extensively investigated. Surprisingly, despite the widespread use of this reaction, double allylic substitution sequences have been little explored and limited exclusively to bifunctional allylic diacetates and dicarbonates. As a function of the nucleophile employed, either linear ${ }^{[3]}$ or cyclic products ${ }^{[4]}$ were isolated. Hence, this methodology was applied to the synthesis of furan or piperazine derivatives. For instance, Tanimori reported the preparation of vinyldihydrofuran 3a via a palladium-mediated bis alkylation of dimedone 1a using the symmetrical allylic diacetate 2 (Scheme 1). ${ }^{[5]}$
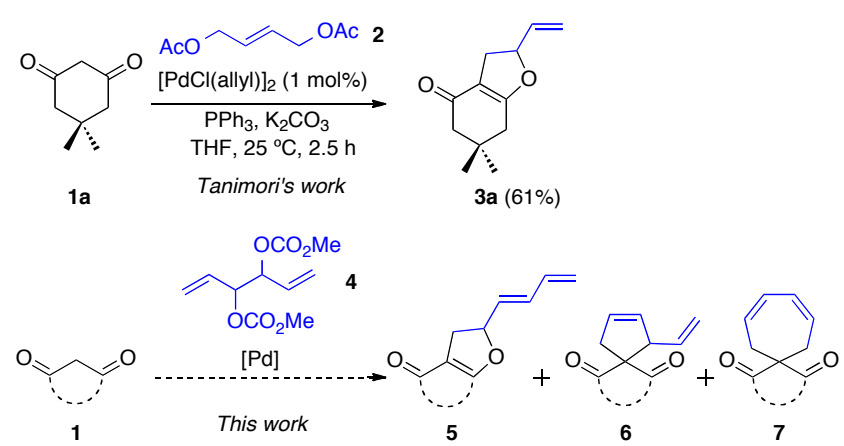

Scheme 1. Palladium-catalyzed bis allylic substitution sequences

Following our continuous interest in metal-promoted formations of carbocycles ${ }^{[6]}$ we were intrigued by the possibility to use hexadiene dicarbonate $4^{[7]}$ in order to form vinylcyclopentene 6 and/or

[*] Dr. Hervé Clavier, Dr. Laurent Giordano, and Dr. Alphonse Tenaglia

Equipe Chirosciences

UMR CNRS 7313 - iSm2, Aix Marseille Université, Ecole

Centrale de Marseille,

Av. Escadrille Normandie-Niemen, 13397 Marseille Cedex 20, France

E-mail: herve.clavier@univ-amu.fr;

laurent.giordano@centrale-marseille.fr; alphonse.tenaglia@univ-amu.fr

[**] We acknowledge the CNRS for fundings. We are grateful to Christophe Chendo and Valérie Monnier for mass spectroscopy analyses and Michel Giorgi for X-ray determination (Spectropole, Fédération des Sciences Chimiques de Marseille)

Supporting information for this article is available on the WWW under http://www.angewandte.org or from the author.

cycloheptadiene 7 in addition of dihydrofuran derivative 5 obtained through sequential C-C then C-C or C-O bond formations (Scheme 1).

As illustrated in Table 1, we started by the examination of the reaction conditions using the benchmark substrates dimedone 1a and dicarbonate 4 . Through the appropriate choice of conditions, it was possible to isolate selectively either compound $\mathbf{5 a}$ or spiro derivative 6a. The structure of 6a was unambiguously confirmed by X-ray determination (Figure 1, left). The use of $\left[\mathrm{Pd}(\text { allyl)Cl }]_{2}\right.$ and $\mathrm{PPh}_{3}$ as catalytic system allowed for the formation of $64 \%$ of vinylcyclopentene $6 \mathbf{a}$ in $8 \mathrm{~h}$ at $25^{\circ} \mathrm{C}$ with traces of 5a (entry 1). Products selectivity was not affected when using $\left[\mathrm{Pd}\left(\mathrm{PPh}_{3}\right)_{4}\right]$ or $\mathrm{Pd}(\mathrm{OAc})_{2}$ (entries 5 and 6). In contrast, $\mathrm{Pd}_{2}(\mathrm{dba})_{3} \cdot \mathrm{CHCl}_{3}$ was able to

Table 1. Palladium-catalyzed bis allylic substitution with 1,3-dione 1a: Effect of Reaction Parameters ${ }^{\mathrm{a}}$

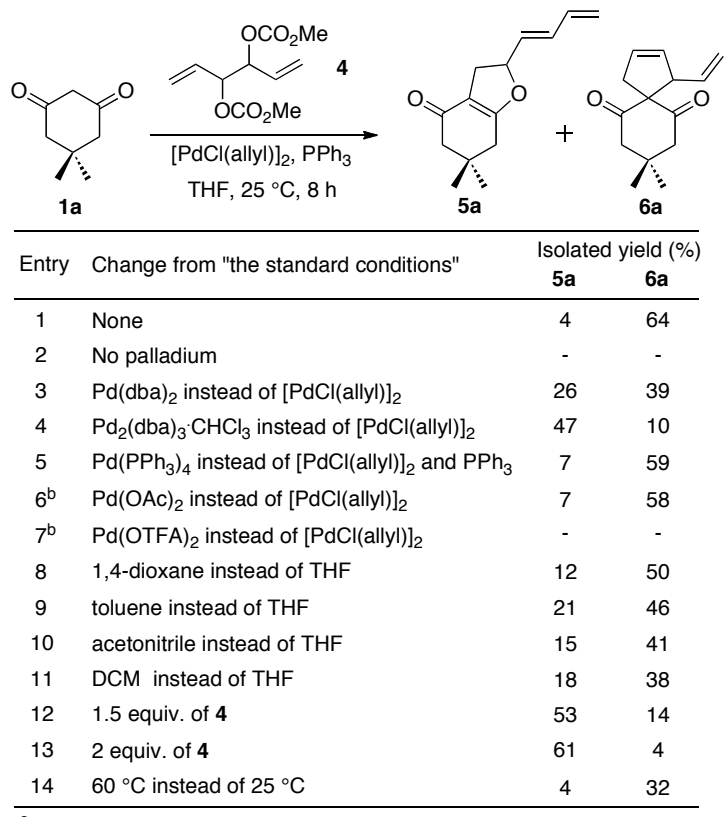

${ }^{a}$ Reaction conditions: [Pd] (5 mol\%), $\mathrm{PPh}_{3}(20 \mathrm{~mol} \%), \mathbf{1 a}(0.5 \mathrm{mmol}), 4$ $(0.5 \mathrm{mmol}), \operatorname{THF}(5 \mathrm{~mL}, 0.1 \mathrm{M}), 25^{\circ} \mathrm{C}, 8 \mathrm{~h}$. ${ }^{\mathrm{b}}$ Palladium and ligand were heated $15 \mathrm{~min}$. at $60{ }^{\circ} \mathrm{C}$ before adding substrates. dba = dibenzylideneacetone; TFA = trifluoroacetyl.

$6 a$

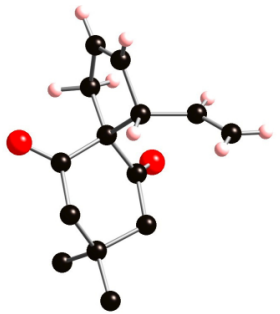

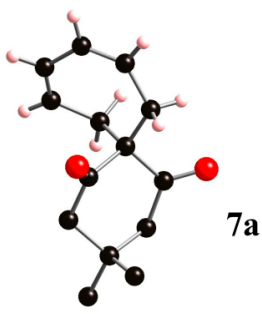

Figure 1. Ball-and-stick representation of compounds $\mathbf{6 a}$ (left) and 7a (right) (some hydrogen atoms have been omitted for clarity) 
reverse selectivity (entry 4) and $\mathrm{Pd}(\mathrm{OTFA})_{2}$ was found ineffective (entry 7). The solvent appeared to play a minor role on the reaction outcome (entries 8-11). Since noticeable amounts of unreacted dimedone 1a were observed at the end of the reaction, a degradation of dicarbonate 4 through a reductive elimination to form 1,3,5hexatriene was assumed. ${ }^{[8]}$ Therefore, an excess of $\mathbf{4}$ was used to improve product 5a formation (entries 12 and 13). Increasing the temperature led to reduce isolated yields as a consequence of degradation processes (entry 14).

In a second time, ligand effect has been carefully scrutinized (Table 2). Electron-rich $\mathrm{PCy}_{3}$ afforded only traces of 5a (entry 3). Electron-poor phosphines such as trifurylphosphine, $\mathrm{P}(\mathrm{OPh})_{3}$, or $\mathrm{P}\left(\mathrm{C}_{6} \mathrm{~F}_{5}\right)_{3}$ gave low yields either in $\mathbf{6 a}$ or $\mathbf{5 a}$ (entries 4-6). The bulky $\mathrm{P}(o-\mathrm{Tol})_{3}$ led to the formation of only spiro product 6a (entry 7). Interestingly, when $\mathrm{P}\left(o-\mathrm{C}_{6} \mathrm{H}_{4} \mathrm{OMe}\right)_{3}$ was employed, a new product, cycloheptadiene $7 \mathbf{a}$, was isolated as major product (66\%) along with $11 \%$ of $\mathbf{6 a}$. The structure of $7 \mathbf{a}$ was unambiguously determined by X-ray crystallography (Figure 2, right). In order to understand the factors governing the formation of $\mathbf{7 a}$, meta- and para-substitued tris(methoxyphenyl)phosphines were tested. These ligands afforded mixtures from which 6a appeared to be the major component (entries 8-10). Meanwhile using $\mathrm{P}\left(2,6-\mathrm{C}_{6} \mathrm{H}_{3}(\mathrm{OMe})_{2}\right)_{3}$ only traces of 5a were isolated. These results suggest that both electron-rich properties and appropriate steric congestion of ligands tend to favor the formation of 7a. Examination of bidentate ligands revealed that Xantphos gave preferentially cycloheptadiene 7a (entries 12-14). This ligand is well-known to present particular coordination modes with participation of its oxygen atom. ${ }^{[9]}$ Thus, secondary interactions of ligand oxygen atoms, such as $\mathrm{P}\left(o-\mathrm{C}_{6} \mathrm{H}_{4} \mathrm{OMe}\right)_{3}$ or Xantphos with the palladium center should be considered to rationalize the formation of $\mathbf{7 a}$.

Table 2. Palladium-catalyzed bis allylic substitution with 1,3-dione 1a: Ligand Effect $^{\mathrm{a}}$

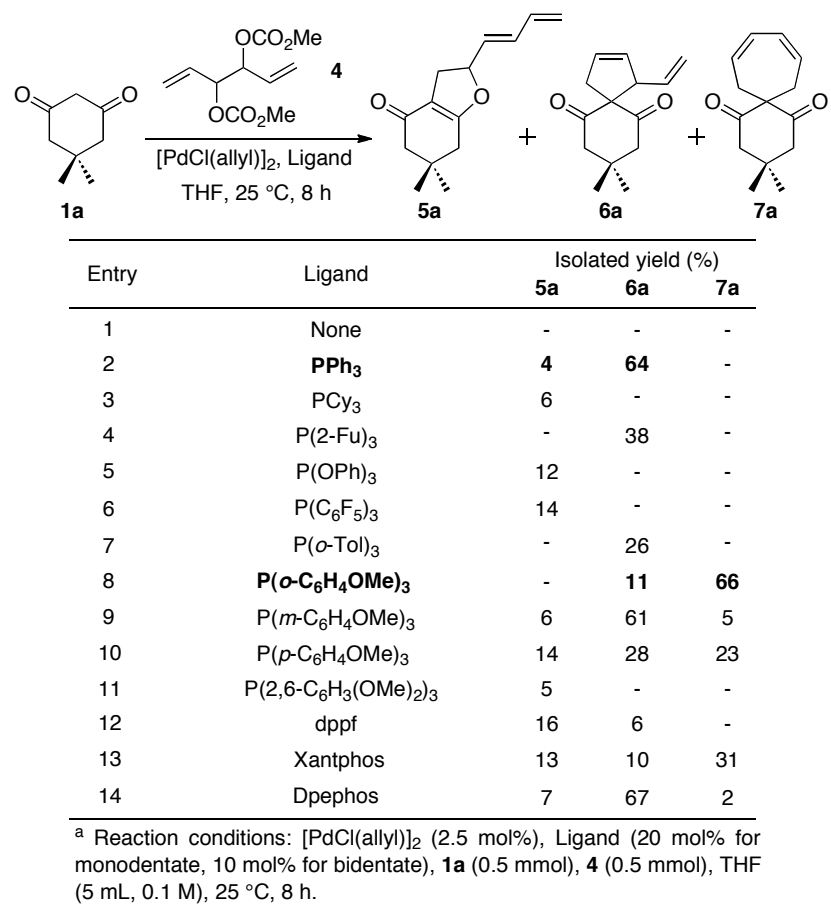

Because examples of palladium-catalyzed 1,3-oxygen-to-carbon alkyl migrations have been reported in the literature ${ }^{[10]}$ dihydrofuran 5a was supposed to be a key intermediate for spirocarbocycles formation. Treatment of $\mathbf{5 a}$ under the usual reaction conditions and $\mathrm{PPh}_{3}$ led to vinylcyclopentene 6a (Scheme
2). When $\mathrm{P}\left(o-\mathrm{C}_{6} \mathrm{H}_{4} \mathrm{OMe}\right)_{3}$ was employed, yields and ratio 6a/7a was found matching with those obtained from dimedone $\mathbf{1 a}$ and $\mathbf{4}$.
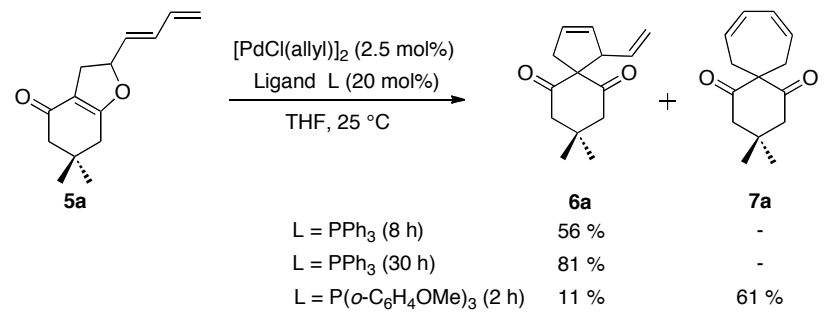

Scheme 2. Conversion of dihydrofuran derivative $\mathbf{5 a}$ into carbocycles $6 \mathbf{a}$ and $7 \mathbf{a}$

Following our efforts to study rearrangement processes, the conversion of $\mathbf{6 a}$ into cycloheptadiene 7a was undertaken (Scheme $3)$. Unexpectedly, the catalytic system including $\mathrm{P}\left(o-\mathrm{C}_{6} \mathrm{H}_{4} \mathrm{OMe}\right)_{3}$ proceeded to the transformation of $6 \mathbf{a}$ into $7 \mathbf{a}$ at $25{ }^{\circ} \mathrm{C}$ with a low yield $(20 \%)$ that was improved further by increasing temperature to $60{ }^{\circ} \mathrm{C}(87 \%$ yield after $3 \mathrm{~h})$. This represents one of the rare examples of palladium-promoted $\mathrm{C}-\mathrm{C}$ allylic bond cleavage, specially at room temperature. ${ }^{[1]}$

When $\mathrm{PPh}_{3}$ was used in the same reaction conditions, no traces of 7 a were detected; $80 \%$ of the starting material was recovered. This confirms that the formation of 7-membered ring occurs only in presence of $\mathrm{P}\left(o-\mathrm{C}_{6} \mathrm{H}_{4} \mathrm{OMe}\right)_{3}$ in the catalytic system. ${ }^{[12]}$

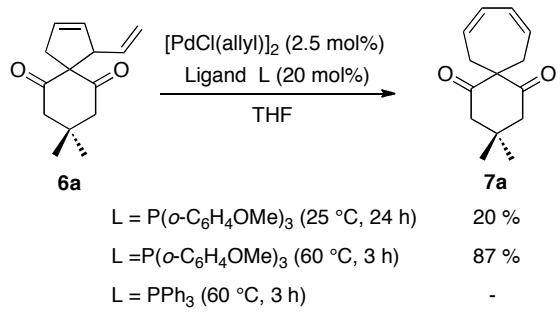

Scheme 3. Transformation of vinylcyclopentene $\mathbf{6 a}$ into cycloheptadiene $7 \mathbf{a}$

Having established the optimal reaction conditions, we then investigated the scope of the formation of vinylcyclopentenes with a range of 1,3-diones or derivatives (Table 3). Cyclopentane-1,3dione-based substrates $\mathbf{1 b}$-1e were good candidates affording the expected vinylcyclopentenes $\mathbf{6 b}-\mathbf{6 e}$ in satisfied yields (entries 1-4). For Cyclohexane-1,3-dione 1f, a moderate yield was obtained (entry 5). ${ }^{[13]}$ Substrate $1 \mathrm{~g}$ allowed to determine that the reaction was not diastereoselective (entry 6). More acidic dicarbonyl compounds such as Meldrum' $\mathbf{s}$ acid 1h, 1,3-dimethylbarbituric acid 1i or 1,2diphenyl-3,5-pyrazolidinedione 1j were well-tolerated (entries 7-9). This led us to examine 5-pyrazolinone $1 \mathbf{k}$ which gave the expected product without any diastereoselectivity but a satisfactory yield (entry 10). In deep contrast, acyclic 1,3-dione such as $\mathbf{1 1}$ gave rise to only traces amounts of $\mathbf{6 l}$ (entry 11). The bulk of the crude reaction mixture consisted in unreacted $\mathbf{1 l}$ and $\mathbf{4}$.

Next, the direct access to cycloheptadienes from various 1,3diones was attempted. Unfortunately, indanedione 1e or pyrazolidinedione $\mathbf{1} \mathbf{j}$ were converted only to vinylcyclopentenes $\mathbf{6 e}$ $(72 \%)$ and $\mathbf{6 j}(55 \%)$ in presence of $[\mathrm{Pd}(\mathrm{allyl}) \mathrm{Cl}]_{2} / \mathrm{P}\left(o-\mathrm{C}_{6} \mathrm{H}_{4} \mathrm{OMe}\right)_{3}$ catalytic system after $2 \mathrm{~h}$ at $60{ }^{\circ} \mathrm{C}$. On the other hand, isomerization of a number of vinylcyclopentenes $\mathbf{6}$ to corresponding cycloheptadienes 7 was achieved under the above conditions in moderate to good yields (Table 4). 
Table 3. Scope investigation for the formation of vinylcyclopentene products $6^{\text {a }}$

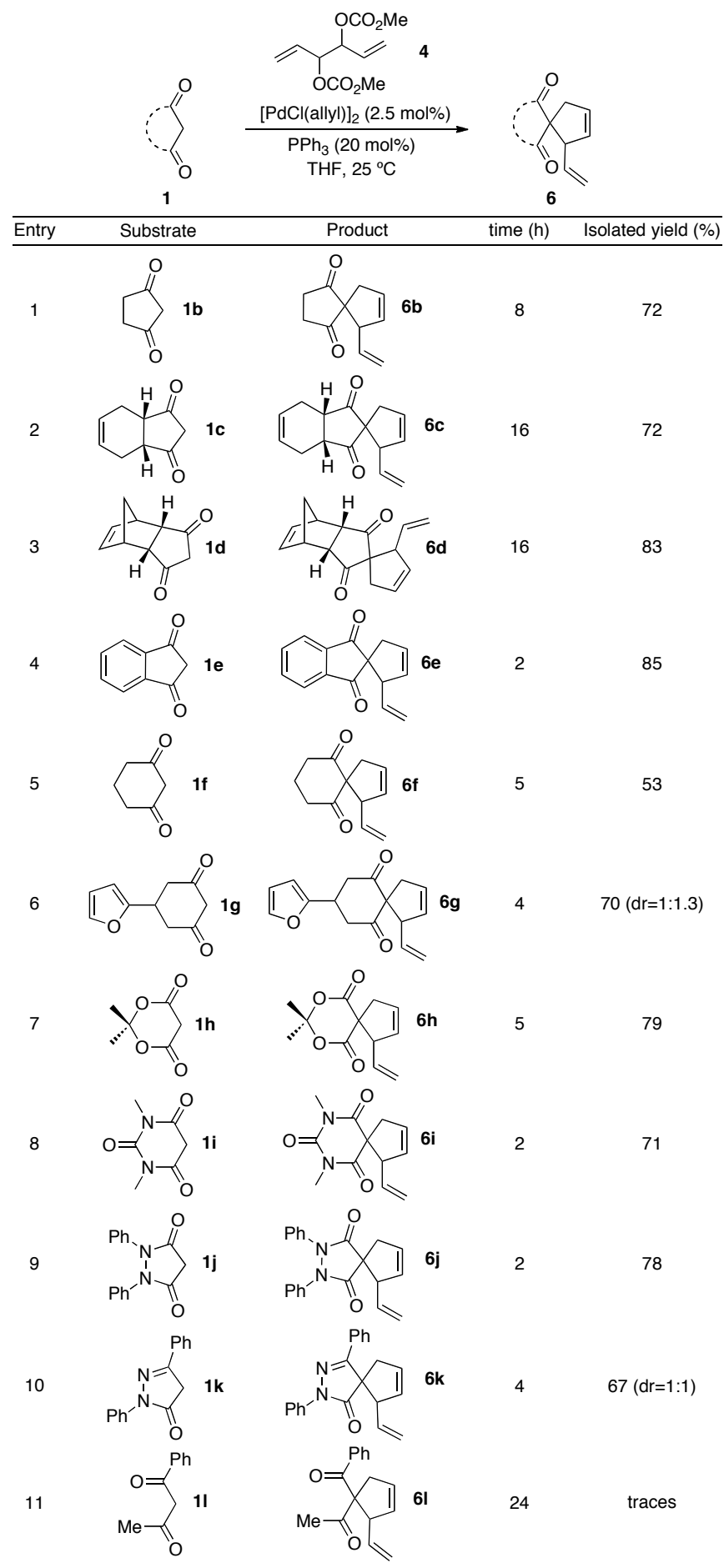

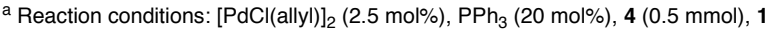
$(0.5 \mathrm{mmol}), \operatorname{THF}(5 \mathrm{~mL}, 0.1 \mathrm{M}), 25^{\circ} \mathrm{C}$

To illustrate the synthetic potential of vinylcyclopentene substrates 6, Meldrum' $\mathrm{s}$ acid derivative $\mathbf{6 h}$ treated with $\mathrm{N}$ bromosuccinimide underwent a bromolactonization to give the bicyclic lactone 8 as a 2.5:1 ratio of diastereomers with a good yield. (Scheme 4). ${ }^{[14]}$
Table 4. Scope examination of the ring expansion ${ }^{a}$

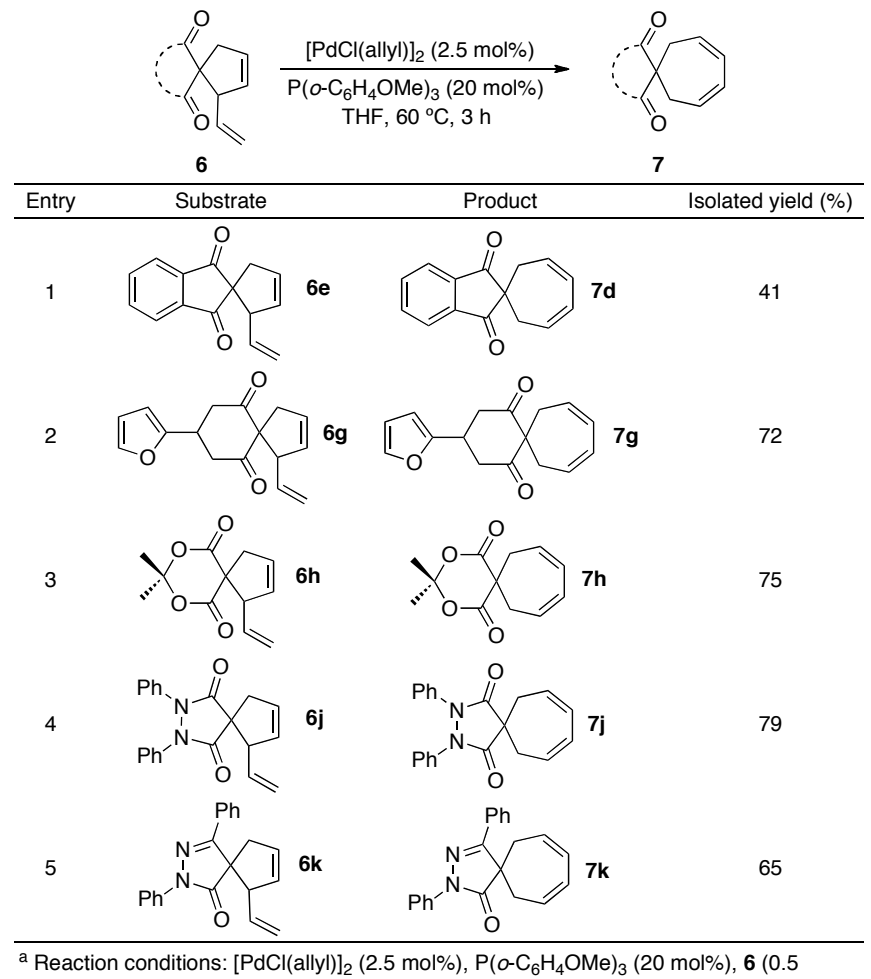
$\mathrm{mmol})$, THF $(5 \mathrm{~mL}, 0.1 \mathrm{M}), 60^{\circ} \mathrm{C}, 3 \mathrm{~h}$.

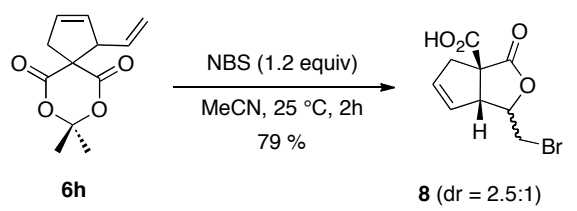

Scheme 4. Bromolactonization of compound $6 \mathrm{~h}$

A plausible mechanism to explain the formation of spirocarbocycles is depicted in scheme 5. At first, an allylic substitution takes place through the intermediate $\mathbf{A}$ to afford monocarbonate $\mathbf{B}$. Then, the oxidative addition process gives rise to the syn,syn $\eta^{3}$-allyl palladium complex $\mathbf{C}$ which can release the kinetic product $\mathbf{5}$ through $O$-alkylation or evolves into the anti,syn $\eta^{3}$-allyl intermediate $\mathbf{D}$ through a $\pi-\sigma-\pi$ isomerization. By a $C$-alkylation, $\mathbf{D}$ leads to vinylcyclopentene $\mathbf{6}$ formation. Dynamic equilibration of $\mathbf{D}$ into syn $\eta^{3}$-allyl complex $\mathbf{E}$ may evolves towards either $\mathbf{6}$ or the less disfavored anti $\eta^{3}$-allyl palladium $\mathbf{F}$ that triggers the formation of cycloheptadiene product 7 . 


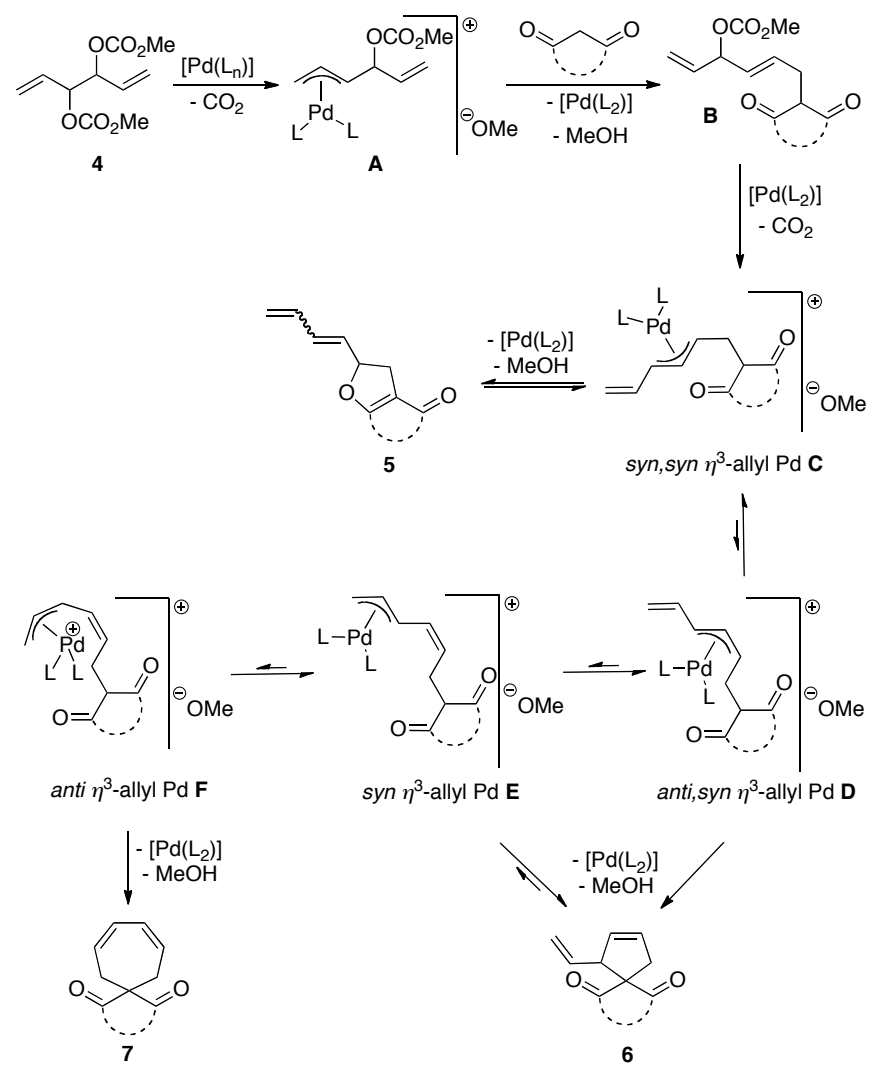

Scheme 5. Mechanistic proposal

In summary, we have developed a palladium-mediated bis allylic substitution leading to 5- and 7 membered carbocycles. The chemoselectivity of the reaction depends on the phosphorous ligand used. More importantly, we observed a cleavage of carbon-carbon allylic bond activation under mild conditions allowing for the isomerization of vinylcyclopentenes into cycloheptadienes. To the best of our knowledge, this metal-catalyzed ring expansion process is unprecedented. Further investigations are underway in our laboratories to better apprehend the mechanism and develop an asymmetric version of this bis allylic substitutions sequence.

Received: ((will be filled in by the editorial staff))

Published online on ((will be filled in by the editorial staff))

Keywords: Allylic substitution - C-C bond activation - Palladium . Phosphine $\cdot$ Spirocycle

[1] a) B. M. Trost, Acc. Chem. Res. 1996, 29, 355-364; b) M. Johannsen, K. A. Jørgensen, Chem. Rev. 1998, 98, 1689-1708; c) S. Norsikian, C.-W. Chang, Curr. Org. Synth. 2009, 6, 264 289.

[2] a) Z. Lu, S. Ma, Angew. Chem. 2008, 120, 264-303; Angew. Chem. Int. Ed. 2008, 47, 258-297; b) B. M. Trost, T. Zhang. J. D. Sieber, Chem. Sci. 2010, 1, 427-440; c) I. G. Rios, A. RosasHernandez, E. Martin, Molecules 2011, 16, 970-1010; d) Transition Metal Catalyzed Enantioselective Allylic Substitution in Organic Synthesis, (Ed. U. Kazmaier), Sringer-Verlag, Heidelberg, Berlin, 2012.

[3] For selected examples of linear products, see: a) J. P. Genêt, M. Balabane, J.-E. Bäckvall, J. E. Nyström, Tetrahedron Lett. 1983,
24, 2745-2748; b) T. Tsuda, M. Okada, S.-i. Nishi, T. Saegusa, J. Org. Chem. 1986, 51, 421-426; c) K. Tsurugi, N. Nomura, K. Aoi, Tetrahedron Lett. 2002, 43, 469-472.

[4] For selected examples of cyclic products, see: a) I. Shimizu, Y. Ohashi, J. Tsuji,. Tetrahedron Lett. 1985, 26, 3825-3828; b) B. M. Trost, G. B. Tometzki, M.-H. Hung, J. Am. Chem. Soc. 1987, 109, 2176-2177; c) T. Tsuda, M. Okada, M.; S.-i. Nishi, T. Saegusa, J. Org. Chem. 1990, 55, 3388-3390; d) Y. Uozumi, A. Tanahashi, T. Hayashi, J. Org. Chem. 1993, 58, 6826-6832; e) M. Massacret, P. Lhoste, R. Lakhmiri, T. Parella, D. Sinou, Eur. J. Org. Chem. 1999, 2665-2673; f) S. Tanimori, M. Kirihata, Tetrahedron Lett. 2000, 41, 6785-6788; g) H. Nakano, J.-i. Yokoyama, R. Fujita, H. Hongo, Tetrahedron Lett. 2002, 43, 7761-7764; h) K. Ito, Y. Imahayashi, T. Kuroda, S. Eno, B. Saito, T. Katsuki, Tetrahedron Lett. 2004, 43, 7761-7764; i) X. Liao, S. Huang, H. Zhou, D. Parrish, J. M. Cook, Org. Lett. 2007, 9, 1469-1471; j) X.-T. Sun, A. Chen, Tetrahedron Lett. 2007, 48, 3459-3461; k) C. S. Chavez, H. Rudler, A. Parlier, P. Herson, Tetrahedron Lett. 2008, 49, 5843-5846; 1) S. Laliberté, P. K. Dornan, A. Chen, Tetrahedron Lett. 2010, 51, 363-366.

[5] S. Tanimori, Y. Kato, M. Kirihata, Synthesis 2006, 865-869.

[6] a) H. Clavier, K. Le Jeune, I. De Riggi, A. Tenaglia, G. Buono, G. Org. Lett. 2011, 13, 308-311; b) T. Achard, A. Lepronier, Y. Gimbert, H. Clavier, L. Giordano, A. Tenaglia, G. Buono, Angew. Chem. 2011, 123, 3614-3618; Angew. Chem., Int. Ed. 2011, 50, 3352-3356; c) A. Tenaglia, S. Marc, L. Giordano, I. De Riggi, Angew. Chem. 2011, 123, 9228-9231; Angew. Chem., Int. Ed. 2011, 50, 9062-9065.

[7] a) N. Nomura, K. Tsurugi, T. V. RajanBabu, T. Kondo, J. Am. Chem. Soc. 2004, 126, 5354-5355; b) B. M. Trost, A. Aponick, J. Am. Chem. Soc. 2006, 128, 3931-3933.

[8] For a reductive elimination of enedicarbonates, see: B. M. Trost, G. B. Tometzki, J. Org. Chem. 1988, 53, 915-917.

[9] For the dynamic coordination environment of Xantphos, see: a) P. W. N. M. van Leeuwen, P. C. J. Kamer, J. N. H. Reek, P. Dierkes, Chem. Rev. 2000, 100, 2741-2770; b) J. R. Martinelli, D. A. Watson, W. M. M. Freckmann, T. E. Barder, S. L. Buchwald, J. Org. Chem. 2008, 73, 7102-7107; c) G. L. Willians, C. M. Parks, C. R. Smith, H. Adams, A. Haynes, A. J. H. M. Meijer, G. J.; Sunley, S. Gaemers, Organometallics 2011, 30, 6166-6179.

[10] a) B. M. Trost, T. A. Runge, L. N. Jungheim, J. Am. Chem. Soc. 1980, 102, 2840-2841; b) B. M. Trost, T. A. Runge, J. Am. Chem. Soc. 1981, 103, 7559-7572.

[11] a) Y. I. M. Nilsson, P. G. Andersson, J.-E. Bäckvall, J. Am. Chem. Soc. 1993, 115, 6609-6613; b) H. Bricout, J.-F. Carpentier, A. Mortreux, Tetrahedron Lett. 1997, 38, 10531056; c) N. Vicart, J. Goré, B. Cazes, Tetrahedron 1998, 54, 11063-11078; d) H. Nakamura, H. Iwama, M. Ito, Y. Yamamoto, J. Am. Chem. Soc. 1999, 121, 10850-10851; e) D. Necas, M. Tursky, M. Kotora, J. Am. Chem. Soc. 2004, 126, 10222-10223; f) E. L. Fisher, T. H. Lambert, Org. Lett. 2009, 11, 4108-4110; g) Y. Sumida, H. Yorimitsu, K. Oshima, Org. Lett. 2010, 12, 2254-2257.

[12] Various experiences to obtain $\mathbf{6 a}$ from $7 \mathbf{a}$ were unsuccessfully conducted.

[13] Small amounts of $\mathbf{5 f}$ were also isolated $(<10 \%)$.

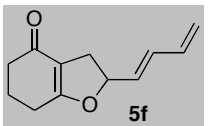

[14] Lactone $\mathbf{8}$ is an advanced intermediate in the synthesis of the cyclic core of Bacillariolides, see: a) H. Miyaoka, M. Tamura, Y. Yamada, Tetrahedron 2000, 56, 8083-8094; b) S.-Y. Seo, J.-K. Jung, S.-M. Paek, Y.-S. Lee, S.-H. Kim, K.-O. Lee, Y.-G. Suh, Org. Lett. 2004, 6 , 429-432; c) S. Ghosh, S. Sinha, M. G. B. Drew, Org. Lett. 2006, 8 , 3781-3784. 


\section{Entry for the Table of Contents}

Layout 2:

\section{Cycles story}

Hervé Clavier, ${ }^{*}$ Laurent Giordano, ${ }^{*}$ and Alphonse Tenaglia* Page

- Page

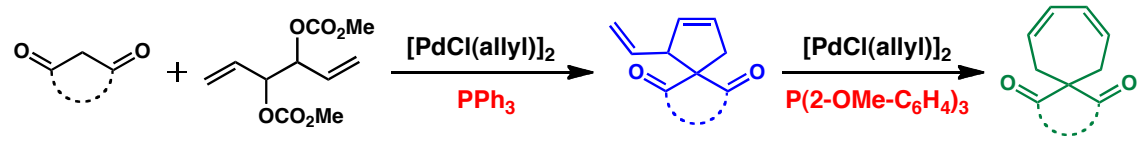

Palladium-mediated phosphine-oriented chemoselective bis allylic alkylation leading to spirocarbocycles

The palladium-catalyzed bis allylic alkylations of 1,3-dione derivatives to afford carbocycles has been investigated. In this transformation, it has been observed that the reaction selectivity was strongly dependent of the phosphine employed.

Moreover, it has been demonstrated that vinylcyclopentenes synthesized could be easily transformed into cyclohexadiene derivatives through a carbon-carbon allylic bond cleavage. 